\title{
Molecular signature of Epstein-Barr virus infection in MS brain lesions
}

Monica A. Moreno, PhD, Noga Or-Geva, PhD, Blake T. Aftab, PhD, Rajiv Khanna, PhD, Ed Croze, PhD, Lawrence Steinman, MD, and May H. Han, MD

Neurol Neuroimmunol Neuroinflamm 2018;5:e466. doi:10.1212/NXI.0000000000000466

\section{Abstract}

\section{Objective}

We sought to confirm the presence and frequency of B cells and Epstein-Barr virus (EBV) (latent and lytic phase) antigens in archived MS and non-MS brain tissue by immunohistochemistry.

\section{Methods}

We quantified the type and location of B-cell subsets within active and chronic MS brain lesions in relation to viral antigen expression. The presence of EBV-infected cells was further confirmed by in situ hybridization to detect the EBV RNA transcript, EBV-encoded RNA-1 (EBER-1).

\section{Results}

We report the presence of EBV latent membrane protein 1 (LMP-1) in 93\% of MS and 78\% of control brains, with a greater percentage of MS brains containing $\mathrm{CD} 138^{+}$plasma cells and LMP-1-rich populations. Notably, 78\% of chronic MS lesions and 33.3\% of non-MS brains contained parenchymal CD $138^{+}$plasma cells. EBV early lytic protein, EBV immediate-early lytic gene (BZLF1), was also observed in $46 \%$ of MS, primarily in association with chronic lesions and $44 \%$ of non-MS brain tissue. Furthermore, $85 \%$ of MS brains revealed frequent EBER-positive cells, whereas non-MS brains seldom contained EBER-positive cells. EBV infection was detectable, by immunohistochemistry and by in situ hybridization, in both MS and non-MS brains, although latent virus was more prevalent in MS brains, while lytic virus was restricted to chronic MS lesions.

\section{Conclusions}

Together, our observations suggest an uncharacterized link between the EBV virus life cycle and MS pathogenesis.

\author{
Correspondence \\ Dr. Han \\ mayhan@stanford.edu
}

From the Department of Neurology and Neurological Sciences (M.A.M., N.O., L.S., M.H.H.), Stanford University School of Medicine, Multiple Sclerosis Center; Interdepartmental Program in Immunology (M.A.M., N.O., L.S., M.H.H.), Stanford; Atara Biotherapeutics (B.T.A., E.C.), San Francisco, CA; and Queensland Institute of Medical Research (R.K.), Brisbane, Queensland, Australia.

Funding information and disclosures are provided at the end of the article. Full disclosure form information provided by the authors is available with the full text of this article at Neurology.org/NN.

The Article Processing Charge was funded by Atara Therapeutics.

This is an open access article distributed under the terms of the Creative Commons Attribution-NonCommercial-NoDerivatives License 4.0 (CC BY-NC-ND), which permits downloading and sharing the work provided it is properly cited. The work cannot be changed in any way or used commercially without permission from the journal. 


\section{Glossary}

CAP = chronic active plaque; $\mathbf{C P}=$ chronic plaque; $\mathbf{D L B C L}=$ diffuse large B-cell lymphoma; EBER = EBV-encoded RNA; EBNA = Epstein-Barr nuclear antigen; EBV = Epstein-Barr virus; FFPE = formalin-fixed, paraffin-embedded; LMP = latency membrane protein; $\mathbf{M B P}=$ myelin basic protein; $\mathbf{N H S}=$ normal horse serum; $\mathbf{P B S}=$ phosphate-buffered saline; $\mathbf{P V}=$ perivascular space; $\mathbf{R T}=$ room temperature.

MS is a chronic, autoimmune-mediated disorder of the CNS, associated with neurodegeneration and progressive neurologic disability. ${ }^{1,2}$ Some studies report Epstein-Barr virus (EBV) in $\mathrm{MS}^{3-7}$ whereas others find no association. ${ }^{8,9}$ Contradictory results have been attributed to differences in methodology and tissue preservation. To date, unequivocal demonstration of EBV infection in MS lesions is lacking.

EBV is a double-stranded DNA $\gamma$-herpes virus that enters $B$ cells via the tonsillar lymphoid tissue. ${ }^{6}$ Within B cells, EBV switches between latent and lytic forms via modulation of EBV nuclear genes, the latent membrane proteins (LMPs) 1, $2 \mathrm{~A}$, and $2 \mathrm{~B},{ }^{10}$ and the viral immediate-early protein, BZLF1 (ZEBRA). ${ }^{11,12}$ The risk of developing MS increases after EBV infection, ${ }^{13,14}$ and EBV infection has been shown to be more prevalent in patients with MS. ${ }^{15,16}$

Previous reports show a high frequency of CNS infiltrating B cells positive for EBV RNA transcript, EBV-encoded RNA (EBER), by in situ hybridization and for the EBV LMP-1 protein. ${ }^{3}$ However, subsequent studies, using identical MS brain tissue, failed to replicate these findings. ${ }^{17,18}$ Here, we demonstrate EBV infection in both MS and control brains, using archived MS and healthy brain samples. We report higher numbers of parenchymal plasma cells and LMP- $1^{+}$ cells in chronic plaques (CPs) and chronic active plaques (CAPs) compared with controls. We observed BZLF1 protein expression in both MS and non-MS brains. However, its expression was restricted to CPs in MS brains.

\section{Methods}

\section{Human brain samples}

We included archived, autopsy brain samples and selected preserved biopsy brain specimens from a panel of $17 \mathrm{MS}$ (mean age 59.3 years [range 29-98 years]; 7 men, 9 women, and 1 without sex specification) and 9 control brains (without neurologic disease) (mean age 72.8 years [range 49-89 years]; 4 men and 5 women) in this study. We did not observe any differences in staining patterns between biopsy and postmortem samples. All samples were processed and subjected to an identical staining protocol. Demographics including age and sex are shown in table. Samples were obtained from the Stanford Pathology Department (Neuropathology Division), the Maritime Brain Tissue Bank, Dalhousie University, and the University of Washington Alzheimer's Disease Research Center, the Adult Changes in Thought Study, and Morris K Udall Center of Excellence for Parkinson's Disease
Research. For MS tissue, areas analyzed included the temporal lobe cortex, occipital lobe cortex, frontal lobe cortex, temporal lobe cortex, and parietal lobe. Human MS brain tissue research was performed according to Institutional Review Board guidelines approved by Stanford Human Subjects Research.

\section{Standard protocol approvals, registrations, and patient consents}

Archived, deidentified autopsy and biopsy brain samples were obtained and used according to the institutional guidelines.

\section{Immunohistochemistry}

Immunohistochemistry was performed on formalin-fixed, paraffin-embedded (FFPE) tissue in 4- $\mu$ m-thick tissue sections. Briefly, slides were deparaffinized in xylene $(3 \times 1$ minute), xylene: $100 \%$ ethanol (at a ratio of 1:1 for 1 minute), $100 \%$ ethanol ( $2 \times 1$ minute), $95 \%$ ethanol ( 1 minute), $70 \%$ ethanol ( 1 minute), and $50 \%$ ethanol ( 1 minute). Slides were then rinsed in cold water and washed in phosphate-buffered saline (PBS). For characterization of cellular infiltration and inflammation, tissue was stained with hematoxylin and eosin $(H \& E)$. For heat-induced antigen retrieval, slides were immersed in $10 \mathrm{nM}$ sodium citrate buffer $(\mathrm{pH} 6)$ and heated in a microwave to $98^{\circ} \mathrm{C}$ for 20 minutes. Slides were then quenched in $0.3 \%$ hydrogen peroxide $\left(\mathrm{H}_{2} \mathrm{O}_{2}\right)$ for 20 minutes to quench endogenous peroxidase activity and rinsed in PBS. To block nonspecific binding of antigens to the tissue, slides were immersed in $2 \%$ normal horse serum (NHS) for 10 minutes at room temperature (RT). Primary antibody was diluted in NHS and incubated overnight at $4^{\circ} \mathrm{C}$. The next day, slides were washed in PBS and incubated with secondary antibody (biotinylated, affinity-purified anti-immunoglobulin; 1:125 dilution in NHS) for 30 minutes at RT. Samples were next washed in PBS and incubated with Elite ABC for 45 minutes at RT. After this incubation, slides were washed once again and stained with freshly made 3,3 ' diaminobenzidine for 1 minute. Samples were then counterstained with hematoxylin for 1 minute, rinsed in water, and then coverslipped with Permount. Immunohistochemistry was performed on the same sections using antibodies against myelin basic protein (MBP) (abcam, ab7349, clone 12; 1:100), CD3 (Dako, M7254, clone F7.2.38; 1:25), CD68 (Dako, M0876, clone PG-M1; dilution 1:50), CD20 (abcam, Ab9475, clone L26; dilution 1:25), CD138 (Sigma, 138M-14, clone B-A38; 1:50), LMP-1 (SC-71023, clone 3H2104,ab,c; dilution 1:100), LMP-1 (SC-57721, clone CS1/2/3/4; 1:200), and EBV ZEBRA (BZLF1) (SC-53904, dilution 1:200). Positive controls included tonsils with infectious mononucleosis and diffuse 
Table Characteristics of MS and healthy control brain samples

\begin{tabular}{|c|c|c|c|c|c|c|c|c|}
\hline Patient & Age/sex & MS type & Lesion type & Region & CD138 & LMP-1 & BZLF1 & $\begin{array}{l}\text { PV/P } \\
\text { (CD138 cells) }\end{array}$ \\
\hline MS-1 & Unknown/M & Tumefactive MS & CAP & $\mathrm{PL}$ & +++ & +++ & - & PV \\
\hline MS-2 & Unknown/unknown & Unknown & CAP & Unknown & + & ++ & - & $P$ \\
\hline MS-3 & $30 / \mathrm{F}$ & Unknown & CAP & $\mathrm{FL}^{\mathrm{a}}$ & + & +++ & - & $P V, P$ \\
\hline MS-4 & $62 / F$ & Tumefactive MS & CAP & $\mathrm{FL}^{\mathrm{a}}$ & +++ & +++ & - & $P$ \\
\hline MS-5 & $42 / F$ & Unknown & CAP & $\mathrm{PL}^{\mathrm{a}}$ & - & ++ & - & PV \\
\hline MS-6 & $39 / M$ & Tumefactive MS & CAP & $\mathrm{TLC}^{\mathrm{a}}$ & +++ & +++ & - & $P V, P$ \\
\hline MS-7 & $29 / M$ & Unknown & CAP & $\mathrm{OLC}^{\mathrm{a}}$ & - & - & - & NA \\
\hline MS-8 & $66 / F$ & Unknown & $\mathrm{CP}$ & TLC & +++ & ++ & + & $P V, P$ \\
\hline MS-9 & $47 / M$ & SPMS & $\mathrm{CP}$ & OLC & +++ & +++ & + & $P V, P$ \\
\hline MS-10 & $50 / \mathrm{M}$ & SPMS & $\mathrm{CP}$ & OLC & +++ & +++ & ++ & $P V, P$ \\
\hline MS-11 & $98 / \mathrm{M}$ & Unknown & $\mathrm{CP}$ & OLC & ++ & +++ & - & $P V, P$ \\
\hline MS-12 & $45 / F$ & Unknown & Unknown & $\mathrm{TLC}^{\mathrm{a}}$ & - & - & - & NA \\
\hline MS-13 & $88 / F$ & Unknown & $\mathrm{CP}$ & $\mathrm{FL}$ & ++ & +++ & - & $P V, P$ \\
\hline MS-14 & $60 / F$ & Unknown & $\mathrm{CP}$ & $\mathrm{FL}$ & + & + & + & $P V, P$ \\
\hline MS-15 & $84 / \mathrm{M}$ & PPMS & $\mathrm{CP}$ & $\mathrm{FL}$ & +++ & +++ & + & $P V, P$ \\
\hline MS-16 & $86 / F$ & PPMS & $\mathrm{CP}$ & OLC & +++ & +++ & ++ & PV \\
\hline MS-17 & $64 / F$ & PPMS & $\mathrm{CP}$ & OLC & +++ & +++ & + & PV \\
\hline Cntl-1 & $66 / F$ & NA & NA & TLC & + & + & ++ & $P V, P$ \\
\hline Cntl-2 & Unknown/unknown & NA & NA & Unknown & ++ & +++ & +++ & $P V, P$ \\
\hline Cntl-3 & $49 / \mathrm{M}$ & NA & NA & OLC & + & - & - & $P$ \\
\hline Cntl-4 & $84 / F$ & NA & NA & OLC & +++ & - & - & PV \\
\hline Cntl-5 & $55 / \mathrm{M}$ & NA & NA & OLC & ++ & ++ & +++ & PV \\
\hline Cntl-6 & $63 / F$ & NA & NA & OLC & - & ++ & - & PV \\
\hline Cntl-7 & $92 / \mathrm{M}$ & NA & NA & OLC & - & + & - & PV \\
\hline Cntl-8 & $89 / F$ & NA & NA & OLC & ++ & + & + & PV \\
\hline Cntl-9 & $71 / F$ & NA & NA & $\mathrm{FL}$ & +++ & + & - & PV \\
\hline
\end{tabular}

Abbreviations: $\mathrm{CAP}=$ chronic active plaque; $\mathrm{CP}=$ chronic plaque; $\mathrm{CNTL}=$ control; $\mathrm{PV}=$ perivascular; $\mathrm{P}=$ parenchyma; $\mathrm{NA}=$ not applicable; $\mathrm{OLC}=\mathrm{occipital}$ lobe cortex; $T L C=$ temporal lobe cortex; $F L=$ frontal lobe; $P L=$ parietal lobe; SPMS = secondary progressive MS; PPMS = primary progressive MS; $L M P-1=$ latent membrane protein 1; BZLF1 = EBV immediate-early lytic gene; syndecan-1 $($ CD138) = a plasma cell marker.

Treatment status of MS cases is unknown.

Semiquantification is expressed as "-" (no cells $\left./ \mathrm{mm}^{2}\right)$, "+" (<5 cells $\left./ \mathrm{mm}^{2}\right), "++$ " (5-10 cells $\left./ \mathrm{mm}^{2}\right)$, and "+++" (>10 cells $\left./ \mathrm{mm}^{2}\right)$.

a Biopsy samples. All other patients shown are autopsy samples.

large B-cell lymphoma. Negative controls included normal tonsils.

\section{In situ hybridization}

In situ hybridization (ISH) was performed on the same FFPE blocks, which were used for immunohistochemistry. The EBER-1 dinitrophenyl (DNP) probe was used to detect the expression of EBER-1 system (ISH iView kit; Ventana Medical Systems Inc., Tucson, AZ, Cat\# 760-097). EBER-ISH was performed using an automated Ventana BenchMark XT system (Ventana Inc.) in accordance with the manufacturer's protocol. Briefly, FFPE sections were treated with EZ Prep buffer (Ventana Inc.) to remove paraffin, rehydrated, and then digested with ISH protease 1 (Ventana Inc., Cat\# 780-4147). EBER 1 DNP probe was then administered and allowed to hybridize, followed by stringency washes as per the manufacturer's instructions using SSC buffer (Ventana Inc., Cat \# 950-110). Slides were counterstained with Red Counterstain II (Ventana Inc., Cat\# 780-2218). Serial sections of all samples were also stained with oligo- $\mathrm{T}$ probes to ascertain RNA 
preservation in each sample. EBV-infected tissue from a tonsil classified as having infectious mononucleosis was used as a positive control for EBER-1. Tonsil tissue obtained from a healthy individual was used as a negative control.

\section{Light microscopy and}

\section{semiquantitative analysis}

All images were acquired using a Zeiss Axio Imager M2 microscope (Carl Zeiss Microscopy), viewed using either 10- or 63-fold magnification. For the purposes of blinding, the tissue samples had only their autopsy or biopsy identifier number. Semiquantification of $\mathrm{CD} 138^{+}, \mathrm{LMP}^{+} 1^{+}$, and $\mathrm{BZLF} 1^{+}$cell numbers was performed by manually counting the number of positive cells having a clearly visible nucleus. The number of cells in a given tissue section was determined by counting cells present in $3 \times 3-\mathrm{cm}$ tissue sections from autopsy samples (MS samples, $\mathrm{n}=11$; controls samples, $\mathrm{n}=9$ ). Biopsy samples (MS samples, $\mathrm{n}=6$; control samples, $\mathrm{n}=0$ ) were used to determine the number of positive cells present in $2 \times 2-\mathrm{cm}$ tissue sections. Results are expressed as follows: no cells $/ \mathrm{mm}^{2}(-)$, $<5$ cells $/ \mathrm{mm}^{2}(+), 5-10$ cells $/ \mathrm{mm}^{2}(++)$, and $>10$ cells $/ \mathrm{mm}^{2}$ $(+++)$. The data sets generated during and/or analyzed during the current study are included in this published article and are also available from the corresponding author on reasonable request.

\section{Results}

\section{Characterization of MS and non-MS brain tissue}

In MS, there are multiple, focal areas of inflammation-driven demyelination in the CNS called plaques or lesions. ${ }^{2}$ They are observed as areas of loss of myelin, characterized by diminished staining with basic protein (MBP) both within and in the surrounding region of the plaque. CAPs are characterized by "a demyelinated area with sharply defined margins and recent areas of inflammatory demyelinating areas at the edges." CAP often contains lymphocytes and macrophage/ microglia within perivascular cuffs and the brain parenchyma. ${ }^{19,20}$ CPs contain "areas of demyelination with well-demarcated borders and abundant astrogliosis, but few or no inflammatory

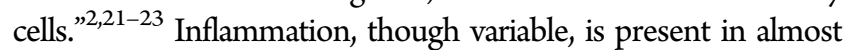
all types of MS plaques observed in the MS brain.

H\&E staining was performed to confirm the presence of inflammatory cell infiltration in active (figure 1A) and to a lesser degree in chronic MS lesions (figure 1B). Inflammatory infiltrates, largely composed of lymphocytes (figure $1 \mathrm{G}$ ) and macrophages (figure $1, \mathrm{~J}$, and $\mathrm{K}$ ), were present to a variable degree in all MS tissue samples studied. Staining with antiMBP confirmed the loss of myelin, which is observed as a loss of brown staining in both active and chronic MS plaques (figure 1, D and E). Staining with CD3 and CD68 shows an increased accumulation of $\mathrm{CD}^{+} \mathrm{T}$ lymphocytes and $\mathrm{CD} 68^{+}$ macrophages/microglia in and around perivascular cuffs in MS lesions (both active and chronic) and control brains (figure 1, G-L). However, the degree of inflammatory cell infiltration decreases with disease duration as seen in CPs (figure $1, \mathrm{H}$ and $\mathrm{K}$ ).

\section{Immunohistochemical detection of B cells and EBV latent and lytic proteins}

To determine the presence and frequency of EBV infection in MS $(n=17)$ and non-MS brains $(n=9)$, we performed immunohistochemistry to determine the expression of the pan B-cell marker (CD20) and plasma cell marker (CD138), in addition to EBV markers LMP-1 and BZLF1 (figure 2). $\mathrm{CD} 20^{+} \mathrm{B}$ lymphocytes and $\mathrm{CD} 138^{+}$plasma cells were observed in all MS (figure 2, A-E) and most non-MS control brain samples (figure 2, C, F, and $\mathrm{M}$ ), although in non-MS tissue, these cells were often confined to the vasculature (figure 2, C and F). However, scarce numbers of CD $138^{+}$ plasma cells ( $64.7 \%$ of $\mathrm{MS} / 33.3 \%$ of control samples) were detected outside the vasculature, most appearing to have migrated into the parenchyma (figure $2 \mathrm{D}$ and table). We next performed immunohistochemistry to detect antibodies recognizing EBV latent or lytic proteins. To detect EBV in its latent form, we used LMP-1, which is an important latently expressed viral protein encoded by EBV. LMP-1 functions, in part, by ensuring efficient maturation of naive $B$ cells into long-lived memory B cells. Its expression coincides with EBV growth programs. LMP-1 staining was observed in both CAPs (figure 2G) and in CPs (figure 2H) and in control brain tissue obtained from healthy individuals (figure 2, I and N). To test for the presence of lytic EBV infection, we measured the presence of a well-documented EBV lytic protein, BZLF1. We observed BZLF $1^{+}$cells in both MS and control brain samples (table and figure $2, \mathrm{~K}$ and $\mathrm{L}$ ).

The frequency of $\mathrm{BZLF}^{+}$staining was enriched in a CP (7 of 9 samples; 78\%) compared with control tissue (4 of 9 samples; 44\%). Notably, we observed no detectable BZLF1 ${ }^{+}$cells in CAPs present in MS tissue (table and figure 2, J and O). As a control, we used immunohistochemistry to detect CD20, CD138, LMP-1, and BZLF1 in tissue sections obtained from a tonsil classified as having infectious mononucleosis (positive control) compared with a disease-free tonsil derived from a healthy individual (negative control). As expected, we detected the presence of $\mathrm{CD} 20^{+} \mathrm{B}$ cells and $\mathrm{CD} 138^{+}$plasma cells in tissue derived from both the infectious mononucleosis and disease-free tonsil (figure 3, A-D). We detected robust expression of EBV LMP-1 and diffuse BZLF1 staining in diseased tissue (figure 3, E and G), while detecting no LMP-1 or BZLF1 in disease-free tonsil tissue (figure $3, \mathrm{~F}$ and $\mathrm{H}$ ).

\section{Detection of EBER transcripts in B cells and plasma cells infiltrating the MS brain}

EBERs (noncoding small RNAs) are expressed in all known forms of EBV latency and serve as the "gold standard" for detecting latent EBV infection. ${ }^{24,25}$ In situ hybridization for EBER-1 transcripts was performed on 7 MS and 4 non-MS brain samples. Sporadic populations of $\mathrm{EBER}^{+}$cells were observed in 6 of $7 \mathrm{MS}$ brain samples (figure 4, B and D), 

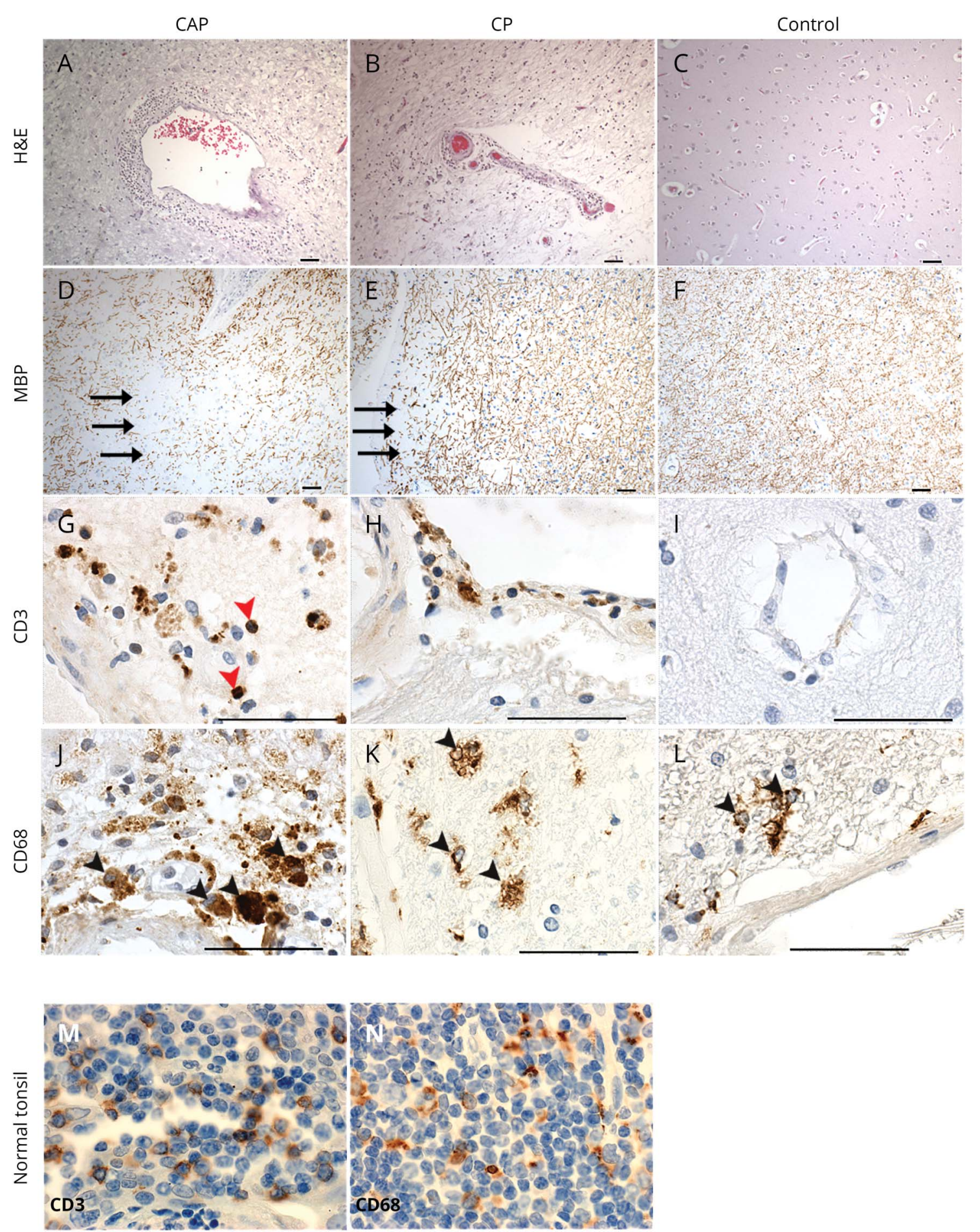

Representative hematoxylin \& eosin (H\&E) staining ( $A-C)$ and immunohistochemistry (D-L) of active MS ( $A, D, G, J)$, chronic MS (B, E, H K), and healthy control $(C, F, I, L)$ brain samples. Perivascular (PV) inflammation (A and B), demyelination, as indicated by the loss of MBP staining (black arrows) (D and E), presence of inflammatory cells, $\mathrm{CD}^{+}$T lymphocytes (red arrowheads) were prominent within active MS lesions (G) and present to a lesser extent in chronic MS lesions (H). Numerous macrophages/microglia (black arrowheads) were observed in and around PV cuffs in active MS (J) and were also observed chronic MS lesions, although to a lesser extent (K). Healthy controls, without neurologic disease, showed little or no CD3 ${ }^{+}$immunoreactivity (I) and positive CD68 ${ }^{+}$immunostaining in the parenchyma resembling resident microglia (black arrowheads) (L). Normal tonsils were used as a positive control and show $C D 3^{+}(M)$ and $C D 68^{+}(N)$ immunostaining. $\mathrm{CAP}=$ chronic active plaque, $\mathrm{CP}=$ chronic plaque. Scale bars $=50 \mu \mathrm{m}$.

whereas only a single $\mathrm{EBER}^{+}$cell was detected in 2 of 4 control samples (figure 4F). RNA preservation was confirmed in all MS and non-MS tissue samples using oligo-T probes (figure 4, A, C, and E). Robust EBER transcript expression was observed in a positive control containing a tonsil with infectious mononucleosis (figure $4 \mathrm{~N}$ ). We performed 

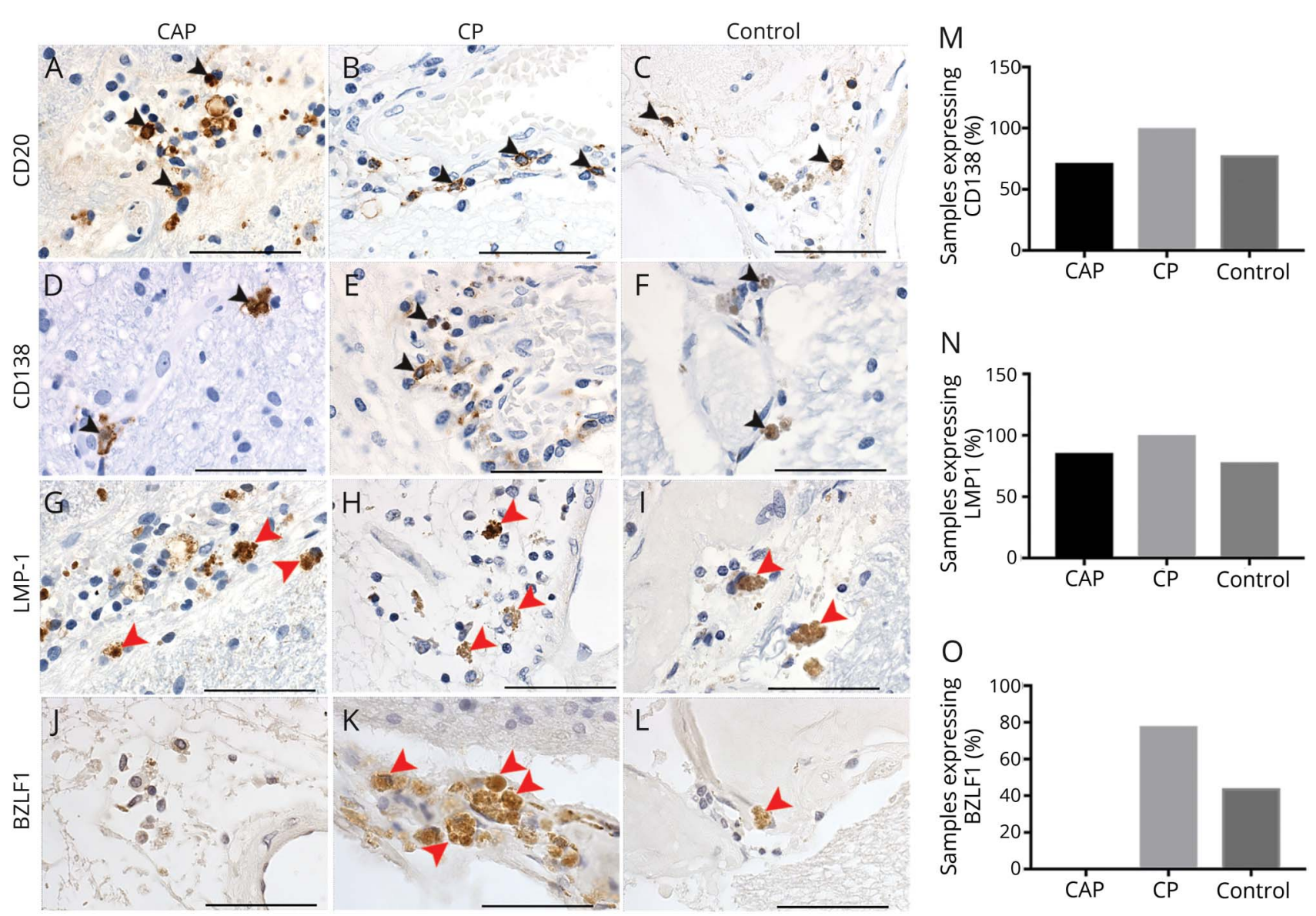

CD20 ${ }^{+} \mathrm{B}$ lymphocytes $(\mathrm{A}-\mathrm{C})$ and $\mathrm{CD} 138^{+}$plasma cells (black arrowheads) (D-F) in the parenchyma and vasculature in a chronic active plaque (CAP) (A and D), in a chronic plaque (CP) (B and E), and in the vasculature of a healthy control brain sample (C and F). Percentage of CAP, CP, and control brain samples expressing CD138 protein detectable by immunohistochemistry are shown (M). We observed latent membrane protein-1 (LMP-1) expression (red arrowheads) in CAP, CP, and control brain samples (G-I). Percentage of CAP, CP, and control brain samples expressing LMP-1 protein detectable by immunohistochemistry are shown (N). Cells expressing LMP-1 (red arrowheads) were found in the vasculature of CAPs (G) and control brains (I), and within the parenchyma in a CP (H). The expression of the viral immediate-early protein BZLF1 was not observed in a CAP (J) and was observed in and around the vasculature in tissue from a CP (red arrowheads) (K). BZLF1 was also observed to a lesser extent in healthy controls (red arrowheads) (L). Percentage of CAP, CP, and control brain samples expressing BZLF1 protein detectable by immunohistochemistry are shown (O). Scale bar $=50 \mu \mathrm{m}$. Pictures are representative of analysis from $17 \mathrm{MS}$ samples and 9 healthy controls. EBV $=$ Epstein-Barr virus.

immunohistochemistry for LMP-1 and in situ hybridization for $\mathrm{EBER}^{+}$cells on serial sections of MS brain samples (figure 4, H, I, K, and L). RNA preservation was confirmed in adjacent sections (Figure 4, G and J). We confirmed colocalized (figure 4, H-I) or proximal (figure 4, K-L) LMP-1 immunoreactivity and $\mathrm{EBER}^{+}$signal (figure $4, \mathrm{H}, \mathrm{I}, \mathrm{K}$, and $\mathrm{L}$ ).

\section{Quantification of B cells and EBV latent and lytic proteins}

MS and control samples were categorized by the number of immunohistologically detectable $\mathrm{CD} 138^{+}, \mathrm{LMP}_{-}{ }^{+}$, and BZLF- $1^{+}$cells $/ \mathrm{mm}^{2}$. Results are grouped accordingly and presented as follows: no cells $/ \mathrm{mm}^{2}(-),<5$ cells $/ \mathrm{mm}^{2}(+)$, $5-10$ cells $/ \mathrm{mm}^{2}(++)$, and $>10$ cells $/ \mathrm{mm}^{2}(+++)$ (table and figure 5). In samples containing less than 10 cells $/ \mathrm{mm}^{2}(-,+$, and ++ ) of either CD138 or LMP-1, we did not observe detectable increases in patients with MS compared with controls (figure 5, A and B). Although results did not reach statistical significance, MS samples had an increased frequency of samples containing greater than 10 cells $/ \mathrm{mm}^{2}$ $(+++)$ of either CD138 or LMP-1 compared with controls (figure 5, A and B), suggesting that control of an EBV infection may be diminished in patients with MS, resulting in an increased presence of EBV-infected plasma cells vs that seen in healthy controls. Conversely, the percentage of samples containing greater than 10 cells $/ \mathrm{mm}^{2}(+++)$ of the lytic phase marker, BZLF1, showed a greater frequency in controls vs MS samples (figure 5C), although this finding was not statistically significant. When comparing the general presence or absence of EBV in MS and controls samples, there was no observable difference in the number of patients expressing CD138, LMP1, or BZLF1-positive cells (figure 5, D-F) ( $\mathrm{n}=17$ patients with $\mathrm{MS}$ and $\mathrm{n}=9$ controls). $\mathrm{CD} 138^{+}$plasma cell numbers found restricted within perivascular spaces $(\mathrm{PV})$ were greater in controls vs both CAP and CP samples (figure 5G). Notably, $33 \%$ of control samples contained parenchymal CD $138^{+}$ 
Figure 3 Immunohistochemical analyses of positive and negative Epstein-Barr virus (EBV) control tissues using immunostaining

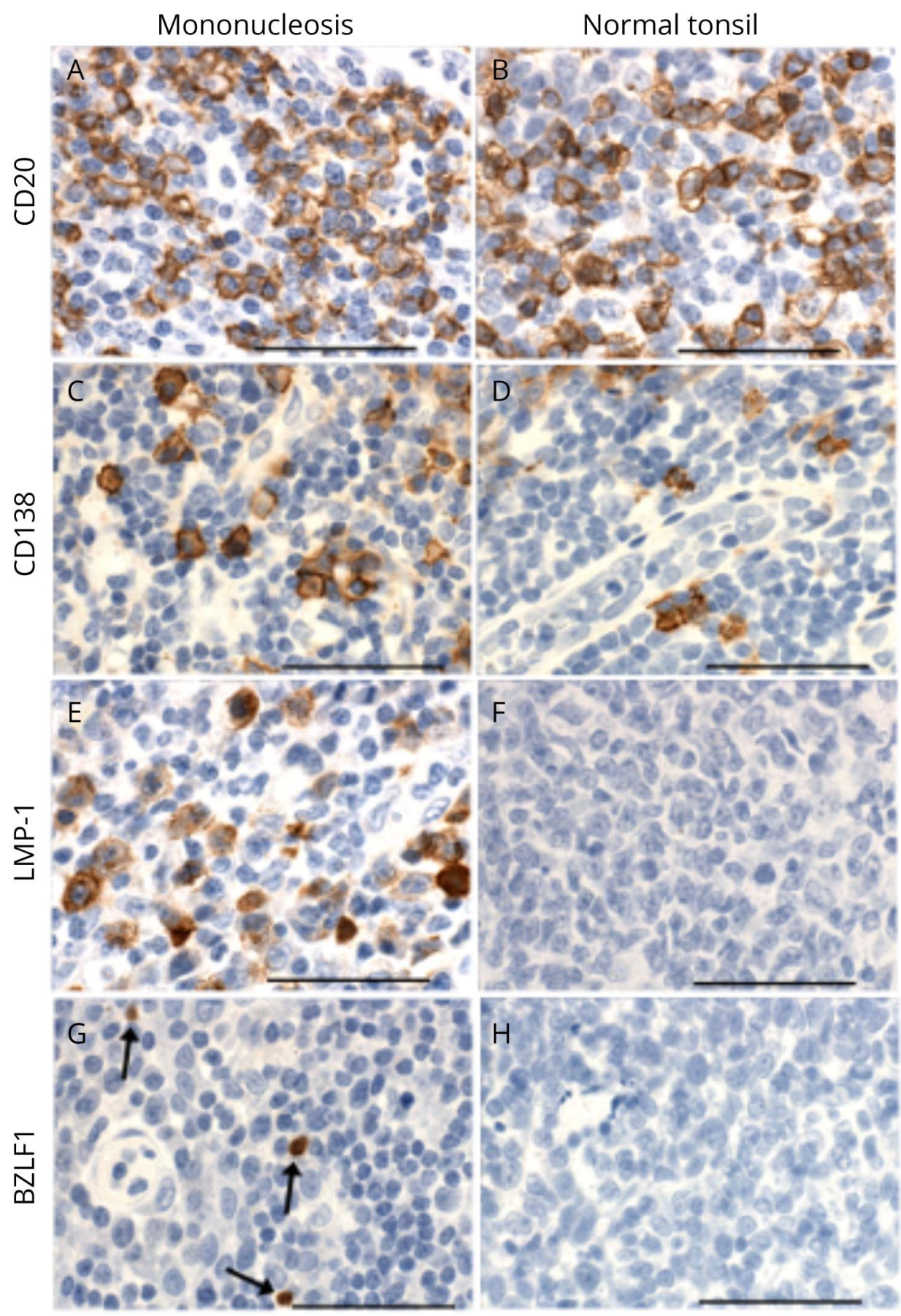

Pictures are representative of results from 2 different experiments using EBVpositive (tonsil with infectious mononucleosis) and EBV-negative (normal tonsil) control samples. Immunohistochemistry revealed the presence of CD20 $\mathrm{B}$ lymphocytes (A-B) and CD138 plasma cells (C-D) in our positive and negative control tissue (A-D). LMP-1 ${ }^{+}$ (brown staining) and $\mathrm{BZLF}^{+}$(brown staining emphasized with black arrows) cells are shown in a tonsil from a patient with infectious mononucleosis ( $E, G)$. No LMP- $1^{+}$or BZLF1 ${ }^{+}$cells were observed in our negative control tissue (normal tonsil) $(F, H)$. Scale bar $=50 \mu \mathrm{m}$.

plasma cells compared with 57\% and 78\% in CAPs and CPs, respectively (figure $5 \mathrm{H}$ ).

\section{Discussion}

EBV infection is estimated to affect upward of $95 \%$ of adults worldwide. ${ }^{26} \mathrm{EBV}$ infection causes infectious mononucleosis, an acute infection with multiorgan involvement. Chronic EBV infection is associated with various types of malignancy, including Burkitt lymphoma and certain head and neck cancers. ${ }^{26,27}$ The notion that EBV may be related to the pathogenesis of MS stemmed from early studies, which showed elevated EBV antibody titers in the sera of MS vs control patients. ${ }^{28}$ Whether MS might result from an immunopathologic response toward an active EBV infection 

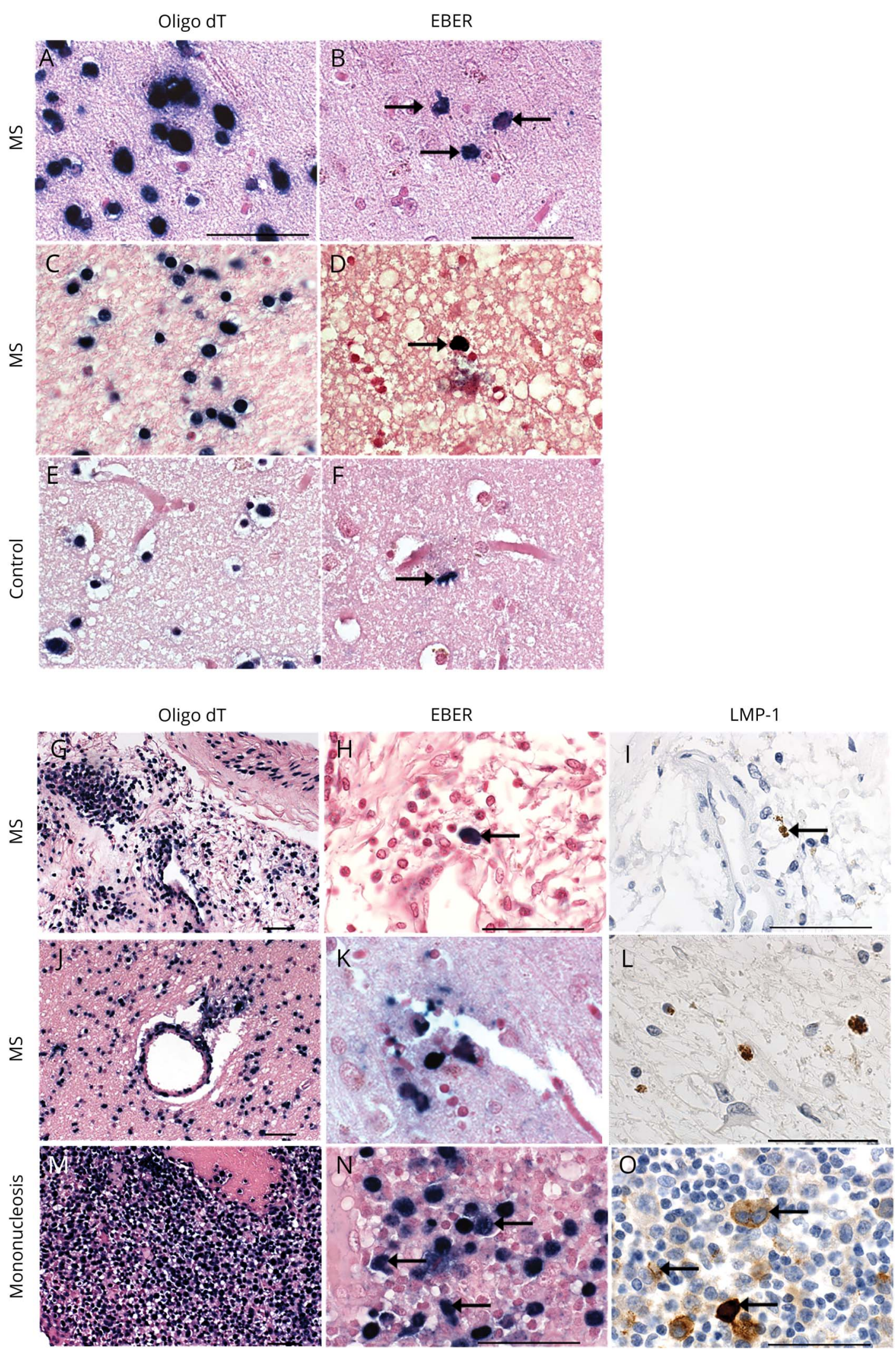

In situ hybridization for EBER detects EBER ${ }^{+}$cells (blue-black nuclei, black arrows) in 4 representative MS brains (B, D, H, and K) and 1 representative control brain (F). In situ hybridization for EBER and immunohistochemistry for LMP-1 show EBER and LMP-1 ${ }^{+}$cells in the same region or nearby regions in 2 representative MS brains (G-L). Tonsil tissue from a patient with infectious mononucleosis (M-O) shows colocalization of EBER and LMP-1. RNA preservation in samples is corroborated by in situ hybridization for oligo $d T$ in serial sections from the same MS and control samples $(A, C, E, G, J$, and $M)$. Scale bar $=50 \mu m$. 

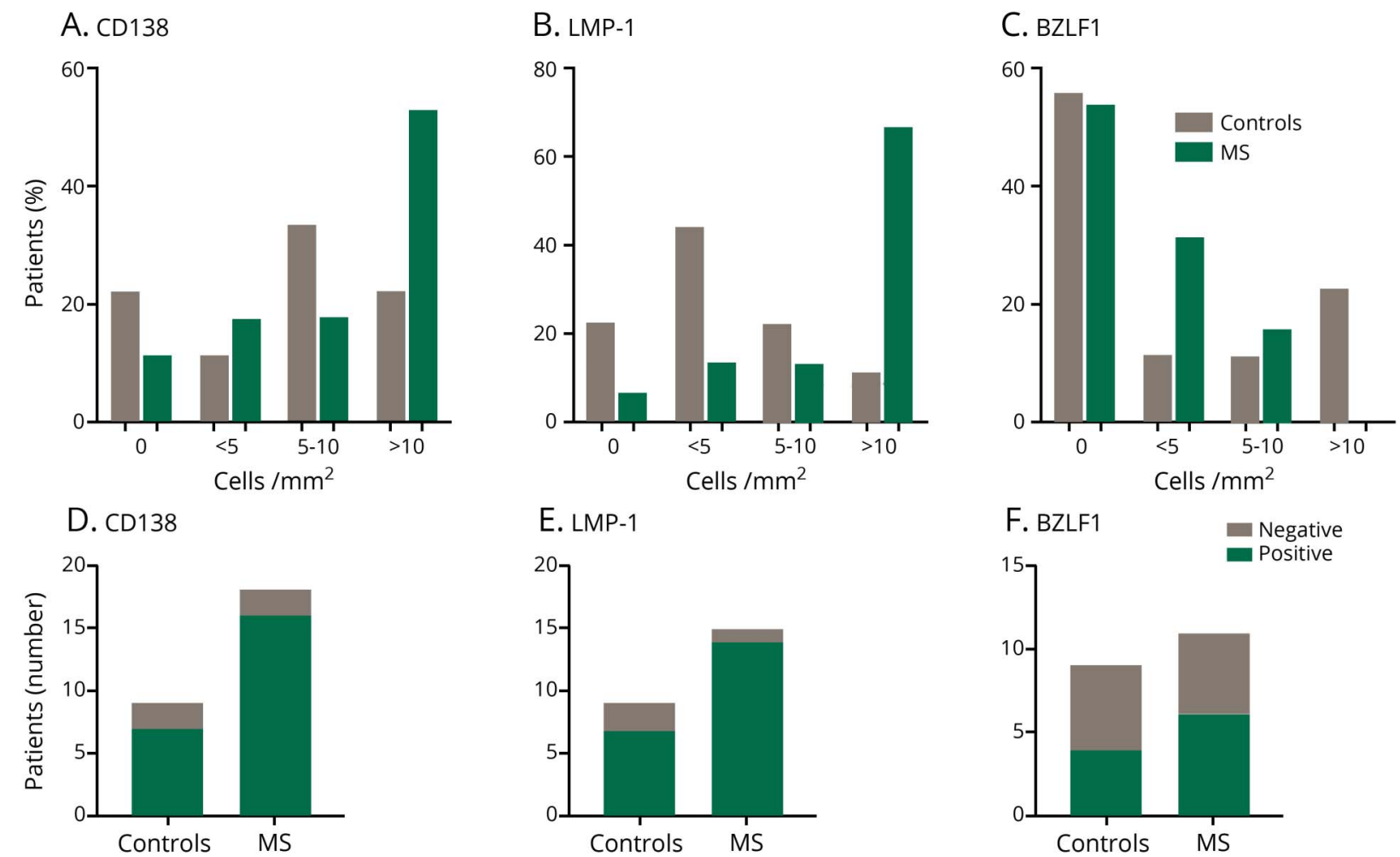

\section{G. Perivascular CD138}

\section{H. Parenchymal CD138}
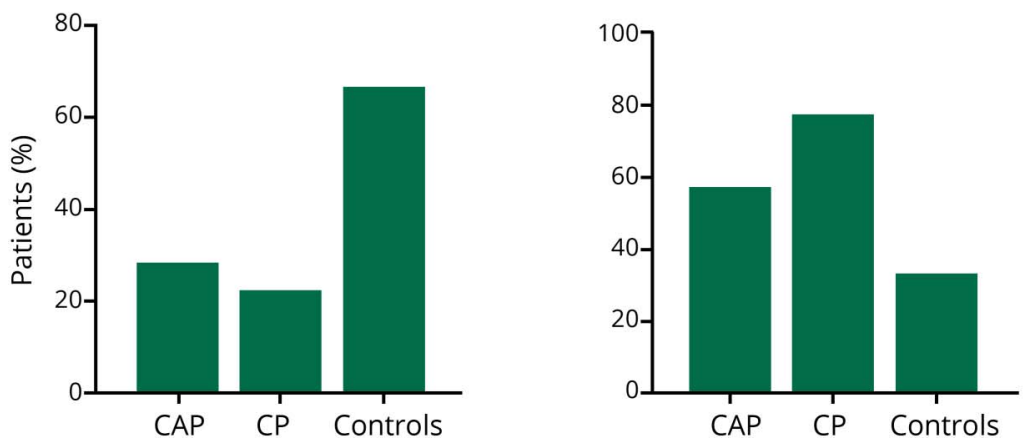

Formalin-fixed paraffin embedded brain tissue from MS and control brains without neurologic disease were cut into 4- $\mu$ m sections. Hematoxylin and eosin (H\&E) and immunohistochemistry were performed using antibodies against latent membrane protein 1 (LMP-1), Epstein-Barr virus (EBV) immediate-early lytic gene (BZLF1), and Syndecan-1 (CD138), a plasma cell marker. For each MS and control sample, the number of CD138 ${ }^{+}$, LMP-1 ${ }^{+}$, and BZLF1 ${ }^{+}$cells with a visible nucleus was counted manually to allow semiquantitative analysis and categorization of these markers. Results are semiquantitative and expressed as percentage of patients expressing as no cells $/ \mathrm{mm}^{2},<5$ cells $/ \mathrm{mm}^{2}, 5-10$ cells $/ \mathrm{mm}^{2}$, and $>10$ cells $/ \mathrm{mm}^{2}$ (A-C). Semiquantitative analysis of CD138 (D) and EBV antigen-positive cells (E,F) in MS and healthy control samples (D-F). CD138 cells in MS and control samples were characterized by their location in perivascular regions or in the parenchyma ( $G$ and $H)$, revealing an increased frequency of parenchymal CD138 ${ }^{+}$cells in CAPs and CPs vs controls $(H)$. The number of cells was counted from samples (MS: $n=11$ autopsy samples and $n=6$ biopsy samples; controls samples: $n=9$ autopsy samples $n=0$ biopsy samples). The number of cells was counted on $3 \times 3-\mathrm{cm}$ autopsy sections and on $2 \times 2$-cm sections for biopsy samples.

brought into the CNS by immigrating B cells has been debated, and investigation has generated contradicting results. Although some studies report EBV in $\mathrm{MS},{ }^{3-7}$ others find no association. ${ }^{8,9}$ Initial studies aimed to show that the presence of EBV in the MS brain by in situ hybridization yielded negative results. ${ }^{29}$ More recent studies using immunohistochemistry, in situ hybridization, and reverse transcriptase PCR techniques in post-mortem MS brains report EBV infection in 21 of 21 brains analyzed. ${ }^{3}$ A similar study, using the same cohort of MS brain samples, detected EBV infection in 2 of 12
MS cases analyzed by similar methodologies. ${ }^{17}$ These contradictory results stem from studies using basically similar technologies. Although technologies may be similar, methodological differences may lead to differences in the sensitivity of the assays. Especially, in the case of postmortem autopsy brain specimens, it becomes crucial to assure proper processing and preservation. Autopsy brain samples with suboptimal tissue preservation may lead to altered assay sensitivity. In addition, there is a wide spectrum of pathologic features of MS lesions, depending on the type and severity of 
the disease and the stage of the lesions. ${ }^{23,30}$ In addition, false positives may be introduced by the use of commercial in situ hybridization detection kits in combination with nonspecific EBV antibodies. ${ }^{23}$ Alternatively, EBV LMP-1 staining, though often strong, may also be focal and weak, thereby contributing to false-negative results. ${ }^{31}$ All of these factors may greatly contribute to variations in assay sensitivity.

Here, we used a well-characterized MS brain tissue bank and an array of specific antibodies and reagents, which are accepted as reagents able to reliably detect LMP-1 and BZLF1 by immunohistochemistry ${ }^{3,17,23,32}$ in combination with in situ hybridization methods considered the "gold standard" approach for detecting EBERs and latent EBV infection. ${ }^{24,25} \mathrm{We}$ also include oligo- $\mathrm{T}$ probes to ascertain RNA preservation in each sample. B lymphocyte and EBV antigen expression in the CNS were detected by both immunohistochemistry and in situ hybridization in the MS brain, although expression was not unique to the MS brain. $\mathrm{CD} 138^{+}$plasma cells were often observed outside the vasculature (in the brain parenchyma) in both chronic and chronic active MS plaque and mainly restricted to PV spaces in control samples, suggesting that the MS brain is more permissible to plasma cell extravasation into the parenchyma. The newly discovered lymphatic vessels in the CNS serve as highways, which can carry immune cells to and from the healthy brain. ${ }^{33} \mathrm{~B}$ cells have been shown to enter all parts of the normal human brain, including the parenchyma, though in low numbers. ${ }^{34,35}$ As MS progresses, $\mathrm{CD} 138^{+}$plasma cells accumulate and persist within the CNS, even in the absence of observed inflammation. ${ }^{22,36}$ It remains unclear whether the extravasation of plasma cells into the parenchyma is dictated by EBV infection or whether MS pathogenesis involves extravasation of EBV-infected plasma cells deep into the tissue, potentially perpetuating the inflammatory response in MS.

In both MS and control samples, LMP-1 immunostaining was predominately observed in the membrane of cells with some staining of the endosomal compartment (figure 2, G-I). In our positive and negative control tissue, LMP-1 revealed predominantly a membrane staining pattern (figure $3 \mathrm{E}$ ). Differences in these staining patterns are likely due to differences in B cells in the brain vs peripheral tissues (control tonsils). LMP-1 is a lipid raft-associated protein, which can accumulate in the lipid-rich rafts on the surface of most B cells. ${ }^{37}$ Endosomes are similar to the composition of lipidrich rafts on the surface of $B$ cells and have been shown to recruit LMP-1 in a CD63-dependent manner. On accumulation within endosomal vesicles, LMP-1 can escape degradation and persist within host $\mathrm{B}$ cells. ${ }^{38}$

Of interest, the lytic form of EBV, as indicated by immunohistologic protein expression of BZLF1, was readily detectable in CPs but not in CAPs. Previous reports depicting BZLF1 staining patterns have been variable. ${ }^{12,39-43}$ Here, we show BZLF1 staining in the MS brain as diffuse cytoplasmic staining along with a darker punctate-like staining (figure $2 \mathrm{~K}$ ).
Our observations are in line with recent studies showing BZLF1 staining in the MS brain. ${ }^{41}$ This staining pattern differs from what we observe in tonsils from a patient with infectious mononucleosis (figure 3G).

EBV lytic proteins, such as BZLF1, can suppress the production of IL-2 and IL- $6 .{ }^{44}$ In addition to its role in B-cell maturation, ${ }^{45}$ IL-6 is known to play an important role in both neurogenesis and oligodendroglia genesis during health and following injury. ${ }^{46}$ In mice with astrocytes, which overexpress IL-6, enhanced revascularization resulted in more rapid healing after traumatic brain injury. ${ }^{47} \mathrm{EBV}$ mediated suppression of pro- and anti-inflammatory cytokines may greatly influence the influx of inflammatory cells, which can serve to clear damaged cells or demyelinated debris in an attempt to repair tissue. Whether lytic EBV can modulate the MS brain microenvironment or whether the MS brain microenvironment (i.e., CPs or CAPs) can modulate the EBV life cycle (i.e., latent or lytic) warrants further investigation.

Previous studies attempting to demonstrate EBV in the MS brain observed the presence of EBV-infected B cells in lymphoid-like B-cell follicles. ${ }^{3}$ These initial studies were challenged by the inability of different groups to consistently identify EBV-infected B cells in cortical structures such as meningeal follicles with germinal centers. We were also unable to identify any lymphoid-like structures in the tissue we examined, leaving open the question of whether such structures exist and whether meningeal B-cell follicles represent an important site for accumulation of EBV-infected B cells in the MS brain.

In summary, we observed that EBV infection is present in both MS and control brains, although EBV-positive cells were more prevalent and more densely populated in the MS brain. The expression of $\mathrm{BZLF}^{+}$cells did not differ between MS and control brains. However, we did not observe BZLF1 expression in CAPs, suggesting that the MS brain may be sensitive to changes in the EBV virus life cycle. Of interest, $85 \%$ of MS brains revealed frequent EBER-positive cells, whereas non-MS brains contained seldom EBER-positive cells. These results corroborate some of the controversial results reported previously for EBER expression in patients with MS. ${ }^{3}$ Taken together, our results that are derived from a well-characterized MS brain tissue bank support previous studies demonstrating the presence of EBV in the MS brain. Further studies investigating the EBV replication cycle and the role of EBVinfected B cells present in meninges and follicular structures in MS brains as it relates to disease pathology and plaque formation are warranted.

\section{Author contributions}

M.A. Moreno, M.H. Han, L. Steinman, B.T. Aftab, and $\mathrm{R}$. Khanna formulated the original problem and provided direction and guidance. M.A. Moreno performed, collected, and analyzed data for IHC and wrote the manuscript. N. Or-Geva 
collected and analyzed data for ISH and IHC. N. Or-Geva, M.H. Han, and L. Steinman reviewed and edited the manuscript.

\section{Acknowledgment}

Brain samples are provided by the Maritime Brain Tissue Bank, Department of Anatomy and Neurobiology, Faculty of Medicine, Dalhousie University, and the University of Washington Alzheimer's Disease Research Center (AG05136), the Adult Changes in Thought Study (AG006781), and Morris K Udall Center of Excellence for Parkinson's Disease Research (NS062684).

\section{Study funding}

Funding was provided by Atara Biotherapeutics.

\section{Disclosure}

M.A. Moreno consulted for and received research support from Atara Biotherapeutics and received research support from the NIH. N. Or-Geva holds a patent for Use of anti-third party cells for treatment of a variety of diseases including cancer and autoimmune disease or as protectors of genetically-engineered cell therapy. B.T. Aftab has been employed by, received research support from, and holds stock/stock options in Atara Biotherapeutics. R. Khanna is on the scientific advisory board of and is a consultant of Atara Biotherapeutics; is the editor-inchief of Clinical \& Translational Immunology; has patents or patents pending for $\mathrm{T}$ cell epitopes and immunotherapy for virus-associated diseases including malignancies and autoimmune diseases; received research support from Atara Biotherapeutics and National Health and Medical Research Council; and holds stock options in and received licensing payments from Atara Biotherapeutics. E. Croze has consulted for Atara Biotherapeutics, Iris Bay is his consulting company. L. Steinman served on the scientific advisory board of Novartis, Receptos, Atreca, Tolerion, Teva, and AbbVie; received travel funding and/or speaker honoraria from Celgene and AbbVie; is on the editorial board of MS Journal and Proceedings National Academy of Sciences; has a patent pending on Cytokines and type 2 interferons; has multiple patents on Antigen specific tolerance; received research support from Atara Biotherapeutics, Celgene, and Biogen; holds stock options and board membership in Tolerion; and is a member of the board of directors of BioAtla. M. Han served on the advisory committee of Novartis; received travel funding and/or speaker honoraria from the University of California, San Diego, and CMSC; consulted for Sanofi Genzyme; and received research support from the Guthy Jackson Charitable Foundation for NMO Research and Leducq Foundation. Full disclosure form information provided by the authors is available with the full text of this article at Neurology.org/NN.

Received December 21, 2017. Accepted in final form April 25, 2018.

\section{References}

1. Fitzner D, Simons M. Chronic progressive multiple sclerosis-pathogenesis of neurodegeneration and therapeutic strategies. Curr Neuropharmacol 2010;8:305-315.

2. Popescu BFG, Pirko I. Pathology of multiple sclerosis : where do we stand ? Continuum (Minneap Minn) 2013;19:901-921.
3. Serafini B, Rosicarelli B, Franciotta D, et al. Dysregulated Epstein-Barr virus infection in the multiple sclerosis brain. J Exp Med 2007;204:2899-2912.

4. Ascherio A, Munger KL. Epstein-barr virus infection and multiple sclerosis: a review. J Neuroimmune Pharmacol 2010;5:271-277.

5. Ascherio A, Munger KL. Environmental risk factors for multiple sclerosis. Part I: the role of infection. Ann Neurol 2007;61:288-299.

6. Nemerow GR, Mold C, Schwend VK, Tollefson V, Cooper NR. Identification of gp350 as the viral glycoprotein mediating attachment of Epstein-Barr virus (EBV) to the EBV/C3d receptor of $\mathrm{B}$ cells: sequence homology of gp350 and C3 complement fragment C3d. J Virol 1987;61:1416-1420.

7. Veroni C, Serafini B, Rosicarelli B, Fagnani C, Aloisi F. Transcriptional profile and Epstein-Barr virus infection status of laser-cut immune infiltrates from the brain of patients with progressive multiple sclerosis. J Neuroinflamm 2018;15:18.

8. Opsahl ML, Kennedy PGE. An attempt to investigate the presence of Epstein Barr virus in multiple sclerosis and normal control brain tissue. J Neurol 2007;254 425-430.

9. Sargsyan SA, Shearer AJ, Ritchie AM, et al. Absence of Epstein-Barr virus in the brain and CSF of patients with multiple sclerosis. Neurology 2010;74:1127-1135.

10. Price AM, Luftig MA. Dynamic Epstein-barr virus gene expression on the path to Bcell transformation. Adv Virus Res 2014;88:279-313.

11. Takada K, Shimizu N, Sakuma S, Ono Y. Trans activation of the latent Epstein-Barr virus (EBV) genome after transfection of the EBV DNA fragment. J Virol 1986;57: 1016-1022.

12. Rooney CM, Rowe DT, Ragot T, Farrell PJ. The spliced BZLF1 gene of Epstein-Barr virus (EBV) transactivates an early EBV promoter and induces the virus productive cycle. J Virol 1989;63:3109-3016.

13. Thacker EL, Mirzaei F, Ascherio A. Infectious mononucleosis and risk for multiple sclerosis: a meta-analysis. Ann Neurol 2006;59:499-503.

14. Nielsen TR, Rostgaard K, Nielsen NM, et al. Multiple sclerosis after infectious mononucleosis. Arch Neurol 2007;64:72-75.

15. Pohl D, Krone B, Rostasy K, et al. High seroprevalence of Epstein-Barr virus in children with multiple sclerosis. Neurology 2006;67:2063-2065.

16. Alotaibi S, Kennedy J, Tellier R, Stephens D, Banwell B. Epstein-Barr virus in pediatric multiple sclerosis. JAMA;291:1875-1879, 2004.

17. Willis SN, Stadelmann C, Rodig SJ, et al. Epstein-Barr virus infection is not a characteristic feature of multiple sclerosis brain. Brain 2009;132:3318-3328.

18. Peferoen LAN, Lamers F, Lodder LNR, et al. Epstein Barr virus is not a characteristic feature in the central nervous system in established multiple sclerosis. Brain 2010;133.

19. Han MH, Lundgren DH, Jaiswal S, et al. Janus-like opposing roles of CD47 in autoimmune brain inflammation in humans and mice. J Exp Med 2012;209. $1325-1334$

20. Han MH, Hwang S, Roy DB, et al. Proteomic analysis of active multiple sclerosis lesions reveals therapeutic targets. Nature 2008;451:1076-1081.

21. Kutzelnigg A, Lucchinetti CF, Stadelmann C, et al. Cortical demyelination and diffuse white matter injury in multiple sclerosis. Brain 2005;128:2705-2712.

22. Frischer JM, Bramow S, Dal-Bianco A, et al. The relation between inflammation and neurodegeneration in multiple sclerosis brains. Brain 2009;132:1175-1189.

23. Lassmann H, Niedobitek G, Aloisi F, Middeldorp JM. Epstein-Barr virus in the multiple sclerosis brain: a controversial issue-report on a focused workshop held in the Centre for Brain Research of the Medical University of Vienna, Austria. Brain 2011; 134:2772-2786

24. Khan G, Coates PJ, Kangro HO, Slavin G. Epstein Barr virus (EBV) encoded small RNAs: targets for detection by in situ hybridisation with oligonucleotide probes. J Clin Pathol 1992;45:616-620.

25. Gulley ML, Tang W. Laboratory assays for Epstein-Barr virus-related disease. J Mo Diagn 2008;10:279-292.

26. Cohen JI, Primary immunodeficiencies associated with EBV disease. Curr Top Microbiol Immunol 2015;390:241-265.

27. Hjalgrim H, Askling J, Sørensen P, et al. Risk of Hodgkin's disease and other cancers after infectious mononucleosis. J Natl Cancer Inst 2000;92:1522-1528.

28. Sumaya CV, Myers LW, Ellison GW. Epstein-Barr virus antibodies in multiple sclerosis. Arch Neurol 1980;37:94-96.

29. Hilton DA, Love S, Fletcher A, Pringle JH. Absence of Epstein-Barr virus RNA in multiple sclerosis as assessed by in situ hybridisation. J Neurol Neurosurg Psychiatry 1994;57:975-976.

30. Lucchinetti C, Brück W, Parisi J, et al. Heterogeneity of multiple sclerosis lesions implications for the pathogenesis of demyelination. Ann Neurol 2000;47:707-717.

31. Gulley ML, Glaser SL, Craig FE. Guidelines for interpreting EBER in situ hybridization and LMP1 immunohistochemical tests for detecting Epstein-Barr virus in Hodgkin lymphoma. Am J Clin Pathol 2002;117:259-267.

32. Niedobitek G, Agathanggelou A, Rowe M, et al. Heterogeneous expression of Epstein Barr virus latent proteins in endemic Burkitt's lymphoma. Blood 2016;86:659-665.

33. Louveau A, Smirnov I, Keyes TJ, et al. Structural and functional features of central nervous system lymphatic vessels. Nature 2015;523:337-341.

34. Blauth K, Owens GP, Bennett JL. The ins and outs of B cells in multiple sclerosis. Front Immunol 2015;6:1-7.

35. Anthony IC, Crawford DH, Bell JE. B lymphocytes in the normal brain: contrasts with HIV-associated lymphoid infiltrates and lymphomas. Brain 2003;126:1058-1067.

36. Moreno M, Bannerman P, Ma J, et al. Conditional ablation of astroglial CCL2 sup presses CNS accumulation of M1 macrophages and preserves axons in mice with MOG peptide EAE. J Neurosci 2014;34:8175-8185.

37. Muntasell A, Berger AC, Roche PA. T cell-induced secretion of MHC class II-peptide complexes on B cell exosomes. EMBO J 2007;26:4263-4272. 
38. Verweij FJ, van Eijndhoven MAJ, Hopmans ES, et al. LMP1 association with CD63 in endosomes and secretion via exosomes limits constitutive NF- $\mathrm{kB}$ activation. EMBO J 2011;30:2115-2129.

39. Angelini DF, Serafini B, Piras E, et al. Increased CD8+ T cell response to Epstein-Barr virus lytic antigens in the active phase of multiple sclerosis. Plos Pathog 2013;9.

40. Sun CC, Thorley-Lawson DA. Plasma cell-specific transcription factor XBP-1s binds to and transactivates the Epstein-Barr virus BZLF1 promoter. J Virol 2007;81:13566-13577.

41. Hassani A, Corboy JR, Al-Salam S, Khan G, Epstein-Barr virus is present in the brain of most cases of multiple sclerosis and may engage more than just B cells. PLoS One 2018;13:e0192109.

42. Frangou P, Buettner M, Niedobitek G. Epstein-Barr virus (EBV) infection in epithelial cells in vivo: rare detection of EBV replication in tongue mucosa but not in salivary glands. J Infect Dis 2005;191:238-242.
43. Calattini S, Sereti I, Scheinberg P, Kimura H, Childs RW, Cohen JI. Detection of EBV genomes in plasmablasts/plasma cells and non-B cells in the blood of most patients with EBV lymphoproliferative disorders by using Immuno-FISH. Blood 2010;116: 4546-4559.

44. Jochum S, Moosmann A, Lang S, Hammerschmidt W, Zeidler R. The EBV immunoevasins vIL-10 and BNLF2a protect newly infected B cells from immune recognition and elimination. Plos Pathog 2012;8:e1002704.

45. Hunter CA, Jones SA. IL- 6 as a keystone cytokine in health and disease. Nat Immunol $2015 ; 16: 448-457$.

46. Erta M, Quintana A, Hidalgo J. Interleukin-6, a major cytokine in the central nervous system. Int J Biol Sci 2012;8:1254-1266.

47. Penkowa M, Giralt M, Lago N, et al. Astrocyte-targeted expression of IL-6 protects the CNS against a focal brain injury. Exp. Neurol 2003:130-148. 


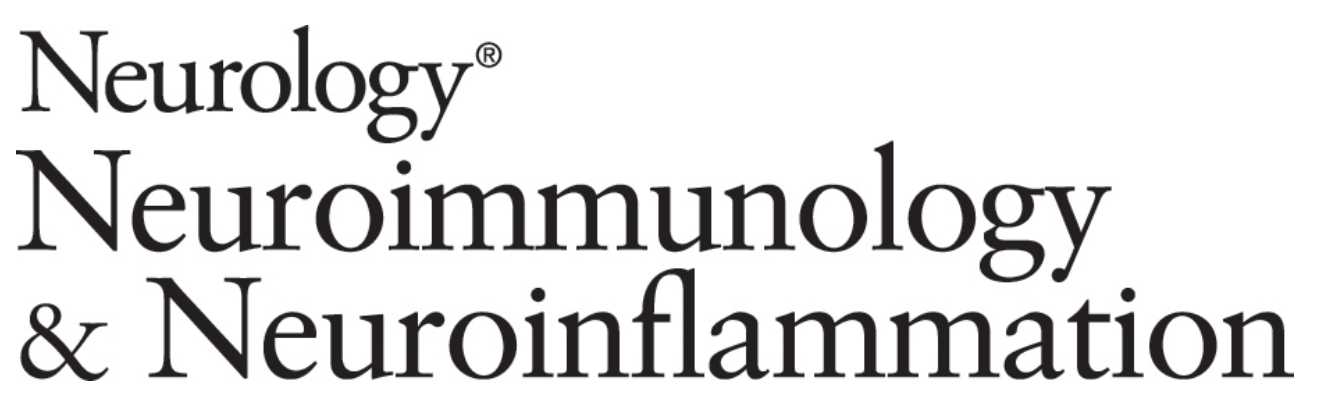

Molecular signature of Epstein-Barr virus infection in MS brain lesions Monica A. Moreno, Noga Or-Geva, Blake T. Aftab, et al.

Neurol Neuroimmunol Neuroinflamm 2018;5;

DOI 10.1212/NXI.0000000000000466

This information is current as of June 7, 2018

Neurol Neuroimmunol Neuroinflamm is an official journal of the American Academy of Neurology.

Published since April 2014, it is an open-access, online-only, continuous publication journal. Copyright

Copyright $\odot 2018$ The Author(s). Published by Wolters Kluwer Health, Inc. on behalf of the American

Academy of Neurology.. All rights reserved. Online ISSN: 2332-7812.

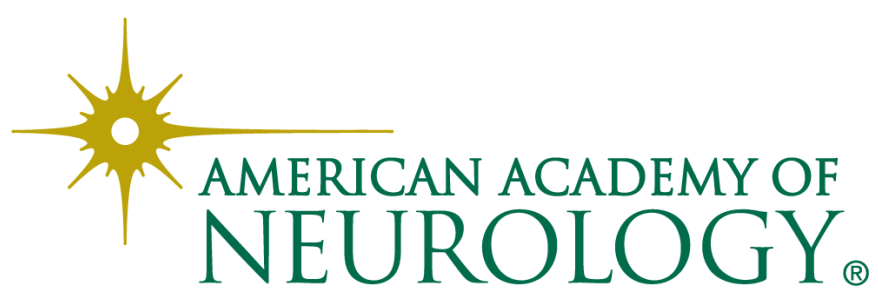




\section{Updated Information \& Services}

References

Citations

Subspecialty Collections

Permissions \& Licensing

Reprints including high resolution figures, can be found at:

http://nn.neurology.org/content/5/4/e466.full.html

This article cites 44 articles, 12 of which you can access for free at: http://nn.neurology.org/content/5/4/e466.full.html\#\#ref-list-1

This article has been cited by 3 HighWire-hosted articles: http://nn.neurology.org/content/5/4/e466.full.html\#\#otherarticles

This article, along with others on similar topics, appears in the following collection(s):

All Clinical Neurology

http://nn.neurology.org//cgi/collection/all_clinical_neurology All Demyelinating disease (CNS)

http://nn.neurology.org//cgi/collection/all_demyelinating_disease_cns All Immunology

http://nn.neurology.org//cgi/collection/all_immunology

Multiple sclerosis

http://nn.neurology.org//cgi/collection/multiple_sclerosis

Viral infections

http://nn.neurology.org//cgi/collection/viral_infections

Information about reproducing this article in parts (figures,tables) or in its entirety can be found online at:

http://nn.neurology.org/misc/about.xhtml\#permissions

Information about ordering reprints can be found online:

http://nn.neurology.org/misc/addir.xhtml\#reprintsus

Neurol Neuroimmunol Neuroinflamm is an official journal of the American Academy of Neurology.

Published since April 2014, it is an open-access, online-only, continuous publication journal. Copyright

Copyright $\odot 2018$ The Author(s). Published by Wolters Kluwer Health, Inc. on behalf of the American

Academy of Neurology.. All rights reserved. Online ISSN: 2332-7812.

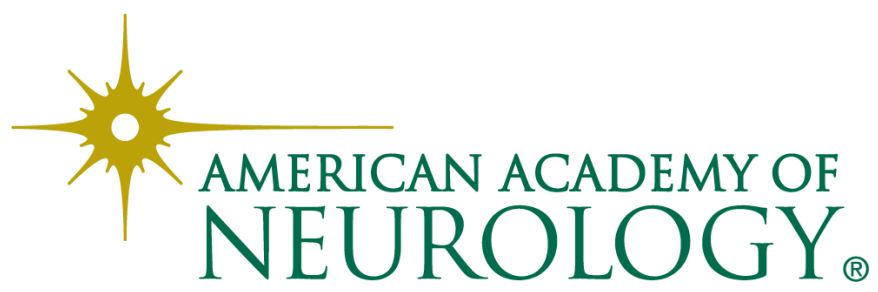

